\title{
Chapter 6 \\ Zoonotic Infections and Biowarfare Agents in Critical Care: Anthrax, Plague, and Tularemia
}

\author{
Ryan C. Maves and Catherine M. Berjohn
}

\section{Introduction}

There are greater than 1400 identified human pathogens. Of these, more than $60 \%$ are of zoonotic origin, infecting humans by means of an animal reservoir [1]. These diseases include ubiquitous viruses like influenza, less common but deadly illnesses like rabies, and neglected parasites such as echinococcosis and cysticercosis. The subset of bacterial zoonoses is similarly varied, with common pathogens in industrialized settings (including Salmonella and Bartonella henselae, the agent of catscratch disease) existing alongside diseases of poverty in the tropics like melioidosis (Burkholderia pseudomallei) and leptospirosis.

In this chapter, we will review three key zoonotic bacterial diseases implicated as potential bioweapons. The use of disease as a weapon has long and inglorious history. As early as the fourth century BCE, Herodotus wrote of Scythian archers dipping their arrows into the decomposing cadavers of humans and snakes prior to firing them at their enemies. The intentional use of smallpox as a weapon of war against Native Americans was historically attested during the French and Indian War. Organized biowarfare programs, with full knowledge of Koch's postulates and the germ theory of disease, began on a small scale during the First World War but expanded dramatically during the interwar years and into the Second World War. The Japanese imperial government is known to have released pathogens directly

R. C. Maves $(\bowtie) \cdot$ C. M. Berjohn

Division of Infectious Diseases, Naval Medical Center, San Diego, CA, USA

Uniformed Services University, Bethesda, MD, USA

e-mail: ryan.c.maves.mil@mail.mil; catherine.m.berjohn.mil@mail.mil 
over regions of China, while Nazi Germany performed human experimentation into biowarfare but did not appear to have utilized them in combat [2].

Following the war, both the United States and Soviet Union had large-scale biowarfare programs until the signing in 1972 of the Convention on the Prohibition of the Development, Production and Stockpiling of Bacteriological (Biological) and Toxin Weapons and on their Destruction (or BWC). Despite the BWC, however, nations continued to conduct research into bioweapons, as demonstrated by the accidental 1979 release of Bacillus anthracis in the town of Sverdlovsk in Russia [3]. In more recent years, non-state entities, such as rogue individuals, cults, and terrorist movements, have come to play a larger role in the use of bioterrorism, most notably the intentional mailing of $B$. anthracis spores in the United States in 2001 [4].

Although the three diseases (anthrax, plague, and tularemia) under discussion are considered potential bioweapons, it is important to recognize that naturally occurring cases of these diseases are far more common than cases of bioterrorism. Indeed, only anthrax has been clearly used as a weapon of terror or war against human targets in modern times. (This is distinct from chemical weapons, which have been used many times in many settings.) Despite this, it is critical that all cases of these diseases be promptly reported to regional and national health authorities whenever they are suspected, in order to safeguard patients, clinical staff, bystanders, and public health.

\section{Anthrax (Bacillus anthracis)}

Bacillus anthracis is an aerobic, gram-positive, spore-forming bacterium which occurs naturally in the soil in many regions of the world. Most commonly a disease of herbivores infected through grazing in contaminated soil, anthrax may be transmitted to humans through exposure to infected animals by consumption, by inhalation of spores from wool or hides, by inoculation of the skin, or more recently by injection of contaminated drugs [5]. Shortly after the September 2001 terrorist attacks in the United States, public fears were again stoked by 22 cases of anthrax due to spores being sent to public figures in the mail, with 5 resulting deaths $[6,7]$. Endemic anthrax remains an important public health threat in developing countries as well as an occasional disease of veterinarians, farmers, and injection drug users in industrialized settings.

B. anthracis produces a trio of plasmid-encoded proteins, protective antigen, edema factor, and lethal factor, which cause its virulence and are potential targets for therapy. Protective factor binds to the other two proteins, creating two toxins (edema toxin and lethal toxin) that mediate tissue injury in humans [8]. Edema toxin impairs intracellular water homeostasis, producing cellular edema. Lethal toxin stimulates high-level production of tumor necrosis factor- $\alpha$ and interleukin-1- $\beta$, leading to lysis of macrophages, release of additional mediators of inflammation, multisystem organ failure, and death [9]. 
Clinical manifestations of anthrax The presenting syndromes of anthrax vary depending on the route of exposure. Cutaneous anthrax comprises up to 95\% of cases, resulting from direct inoculation of B. anthracis spores through skin breaks or injection, followed by germination, soft tissue necrosis, and a black "coal-like" eschar which is painless. (This lesion is the source of anthrax's name, from the Greek word for "coal.") Frequently, a surrounding rim of edema may surround the eschar, which sloughs off within 3 weeks of onset [10]. Fever, lymphangitis, and painful proximal lymphadenopathy typically accompany the lesion. Secondary hematogenous spread of the disease is common, with a mortality of $10-40 \%$ in untreated cases [11] (Fig. 6.1).

Gastrointestinal and oropharyngeal anthrax are rare forms of anthrax, most reported in rural parts of the developing world (including sub-Saharan Africa, as well as Eastern, Southern, and Central Asia). Both occur after the ingestion of contaminated and undercooked meat. In oropharyngeal disease, mucosal edema and ulceration are followed by the development of pharyngeal pseudomembranes, with the potential for airway obstruction. Gastrointestinal anthrax is highly lethal, with necrosis developing throughout the entire gastrointestinal tract with resulting pain, fever, nausea, dysentery, visceral perforation, and sepsis. In the oropharyngeal form, pseudomembranes are seen in the oropharynx, and upper airway obstruction can develop. In the gastrointestinal form, a necrotizing infection progresses from the esophagus to the cecum. Fever, nausea, vomiting, abdominal pain, gastrointestinal bleeding, and bloody diarrhea are typical symptoms. Death results from intestinal perforation or sepsis $[12,13]$.

Inhalational anthrax is the most lethal form of the disease, resulting from the deposition of anthrax spores into the alveoli following inhalation. Following phagocytosis by pulmonary macrophages, $B$. anthracis is transported via lymphatics to the mediastinal lymph nodes. After a period of dormancy which may last between 10 and 60 days, the endospores germinate, release edema and lethal toxin, and produce a fulminant and often lethal illness. The typical clinical course of inhalational

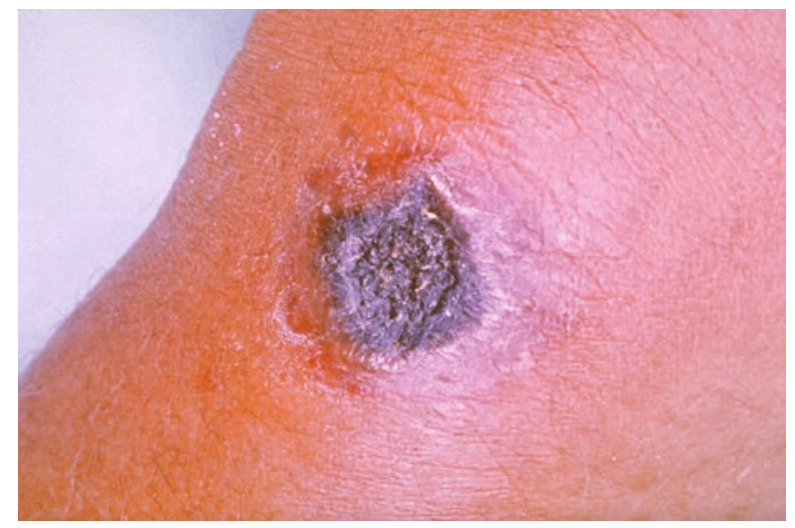

Fig. 6.1 The lesion of cutaneous anthrax, with a black central necrotic lesion surrounded by a rim of edema. (Source: Public Health Information Library, Centers for Disease Control and Prevention. Accessed online on 11 March 2019 at https://phil.cdc.gov/details_linked.aspx?pid=2033) 
anthrax is biphasic, with an initial nonspecific syndrome including fever, dry cough, dyspnea, chest pain, and myalgia that may resemble a typical viral respiratory infection. After 2-3 days, severe illness follows, with hemorrhagic mediastinitis, respiratory failure, and shock [14]. Mediastinal widening and large pleural effusions are common findings; airspace opacities on chest radiography are less frequent, although a hemorrhagic necrotizing pneumonitis has been noted on autopsy specimens [15]. Clinically significant pericardial effusions and ascites occurred in 17\% and $21 \%$ of victims in the Sverdlovsk outbreak, respectively, and may require drainage [16]. Bacteremia is typical and leads to a secondary meningitis in half of cases on inhalational anthrax, requiring aggressive therapy [16] (Fig. 6.2).

The diagnosis of anthrax is complex and requires a high index of suspicion, given the infrequency of this disease in industrialized countries. Typical laboratory findings include a neutrophil-predominant leukocytosis (from normal ranges to 49,600 cells per $\mu \mathrm{L}$ ), elevated liver transaminases, hyponatremia, and hypoxemia $[17,18]$. Chest radiography demonstrates mediastinal widening and pleural effusions, with consolidation and infiltrates less frequent. Mediastinal widening in particular is strongly suggestive of anthrax in the appropriate clinical syndrome and mandates it consideration as a diagnosis $[18,19]$.

Close coordination with hospital microbiology laboratories, as well as public health laboratories, is critical for the diagnosis of anthrax. Large gram-positive rods in short chains that are positive on India ink staining are presumptive of $B$. anthracis until confirmatory tests are obtained. Special culture methods are generally not necessary, as $B$. anthracis grows readily from clinical specimens on conventional media. Routine Biosafety Level 2 conditions and biosafety cabinets are adequate for staff safety. In general, most hospital laboratories will not fully characterize a suspected anthrax specimen; confirmatory testing will be performed by public health laboratories via the Centers for Disease Control and Prevention (CDC) Laboratory Response Network in the United States, Public Health England or Health Protection

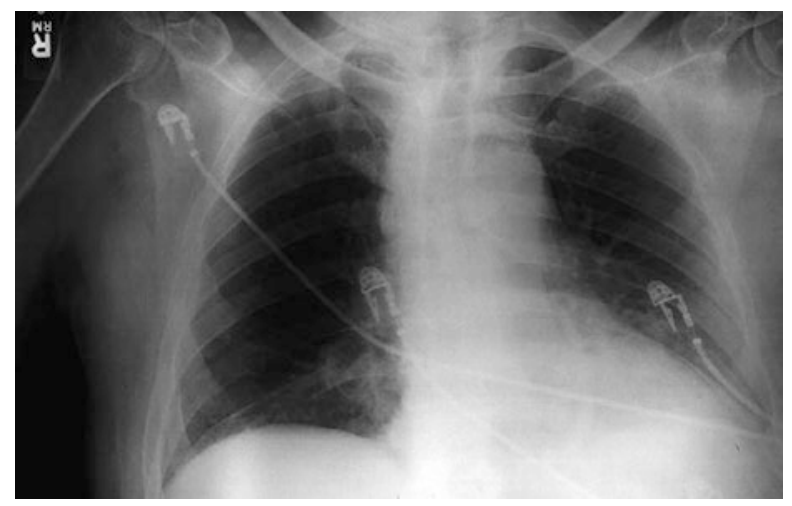

Fig. 6.2 Anteroposterior radiograph of the chest in a patient with inhalational anthrax, with a prominent superior mediastinum and possible small left pleural effusion. (Source: Jernigan JA et al. Emerg Infect Dis 2001;7:933-944) 
Scotland in the United Kingdom, or comparable national agencies. In the United States, advanced anthrax diagnostics are available through the CDC, the US Army Medical Research Institute for Infectious Diseases (USAMRIID), and the Naval Medical Research Center (NMRC), including serologic testing, immunohistochemistry, and polymerase chain reaction (PCR) [20]. Recommended clinical specimens for analysis will vary by presenting syndrome and include blood culture, serum for antibody testing, plasma for direct detection of lethal factor, serosal fluid, cerebrospinal fluid, and tissue from biopsy of cutaneous eschars. A complete guide by syndrome is available from the CDC website at https://www.cdc.gov/anthrax/ specificgroups/lab-professionals/recommended-specimen.html.

The treatment of anthrax also varies based on clinical syndrome and is divided into meningeal and non-meningeal disease for purposes of antimicrobial therapy. Given the increased severity and intensity of therapy for anthrax meningitis, it is recommended that patients receive either confirmation of the diagnosis via early lumbar puncture or empiric therapy directed against meningitis [21]. It is important to recognize that mortality for inhalational anthrax, with or without meningitis, carries an exceptionally high mortality even with appropriate therapy. Despite this, general critical care principles of respiratory, hemodynamic, and other organ system-based support still apply.

The empiric antimicrobial management of anthrax includes an intravenous fluoroquinolone (ciprofloxacin, levofloxacin, or moxifloxacin) with a carbapenem (meropenem or imipenem) and either a protein synthesis inhibitor or rifampin. Either clindamycin or linezolid is acceptable as a protein synthesis inhibitor; rifampin indirectly blocks protein synthesis through the inhibition of RNA polymerase (and thus messenger RNA synthesis) and appears to have comparable efficacy. Non-meningeal disease may be treated with either a fluoroquinolone or a carbapenem in combination with a protein synthesis inhibitor. Once antimicrobial susceptibility has been determined, intravenous penicillin $\mathrm{G}$ or ampicillin may be used in lieu of a carbapenem for susceptible isolates (see Tables 6.1 and 6.2).

Given the high risk of maternal and fetal death in anthrax infections, pregnant women should receive the same therapy as non-pregnant adults [22]. Uncomplicated cutaneous anthrax can be treated with oral ciprofloxacin or doxycycline for 7-10 days. Since concomitant inhalational exposure is difficult to exclude, however, an extended course of 60 days of therapy is usually preferred [23, 24].

In addition to antimicrobial drug therapy, routine intensive care support measures should be provided to critically ill patients with anthrax. Peritoneal effusions and ascites may serve as reservoirs for lethal toxin [25], and serosal drainage has been associated with survival in retrospective cases $[18,26]$. Hemodynamic support with vasopressors may be provided as per standard practice for patients in shock; although there is limited data on the use of adjunctive corticosteroids, it is interesting to note that lethal toxin appears to repress the glucocorticoid receptor [27], and corticosteroids may have utility in the treatment of anthrax-associated airway edema in addition to vasopressor-resistant shock [20].

In combination with antibiotics and (if indicated) corticosteroids, immunotherapy is available to be given in combination with antibacterial therapy. Raxibacumab 
Table 6.1 Intravenous therapy for anthrax with meningitis or if meningitis has not yet been excluded

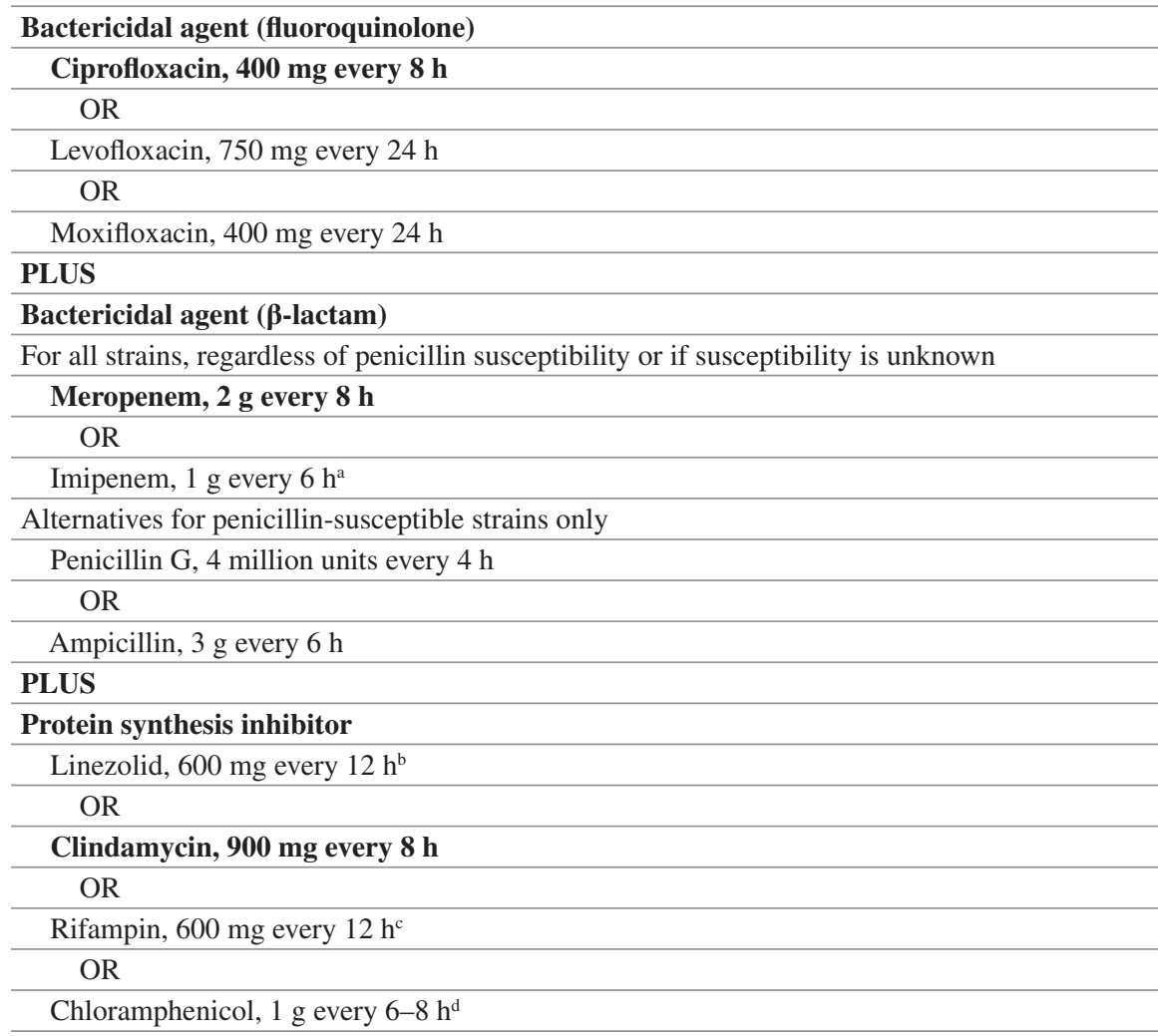

Duration of treatment: $\geq 2-3$ weeks until clinical criteria for stability are met. Patients exposed to aerosolized spores will require prophylaxis to complete an antimicrobial drug course of 60 days from onset of illness. Preferred drugs are indicated in boldface

ancreased risk for seizures associated with imipenem/cilastatin treatment

${ }^{b}$ Linezolid should be used with caution in patients with thrombocytopenia. Linezolid use for $>14$ days has additional hematopoietic toxicity

${ }^{c}$ Rifampin is not a protein synthesis inhibitor. However, it may be used in combination with other antimicrobial drugs on the basis of its in vitro synergy

${ }^{\mathrm{d}}$ Should only be used if other options are not available because of toxicity concerns

Recommendations derived from Hendricks et al. [20]

and obiltoxaximab are two distinct monoclonal antibodies directed against protective antigen [28-31]. Anthrax immunoglobulin intravenous (AIGIV) is a purified polyclonal preparation of anti-anthrax immunoglobulin derived from vaccinated donors [32]. All three are either approved or have orphan drug status in the United States and the European Union, but none are commercially available and must be obtained from the CDC's Strategic National Stockpile. In the absence of comparative human trials, all three are reasonable options to be administered to suspected or confirmed anthrax victims. 
Table 6.2 Intravenous therapy for anthrax when meningitis has been excluded

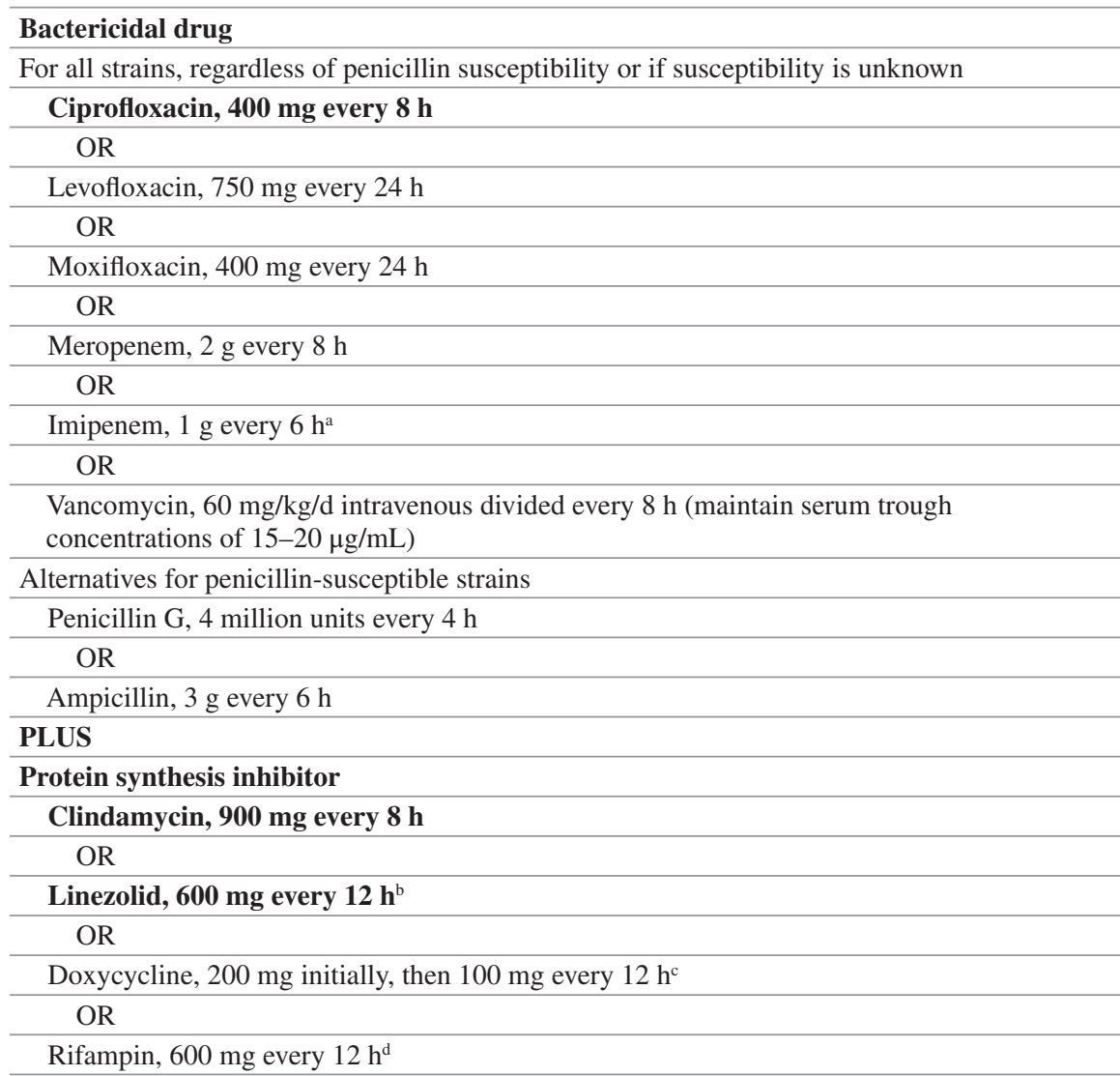

Duration of treatment: for 2 weeks until clinical criteria for stability are met. Patients exposed to aerosolized spores will require prophylaxis to complete an antimicrobial drug course of 60 days from onset of illness. Preferred drugs are indicated in boldface

ancreased risk for seizures associated with imipenem/cilastatin treatment

'Linezolid should be used with caution in patients with thrombocytopenia because it might exacerbate it. Linezolid use for $>14$ days has additional hematopoietic toxicity

${ }^{\mathrm{c}}$ A single 10-14-day course of doxycycline is not routinely associated with tooth staining

${ }^{\mathrm{d}}$ Rifampin is not a protein synthesis inhibitor. However, it may be used in combination with other antimicrobials drugs on the basis of its in vitro synergy

Recommendations derived from Hendricks et al [20]

Prophylaxis for patients exposed to anthrax should include either oral ciprofloxacin (500 mg twice daily), levofloxacin (750 mg daily), or doxycycline (100 mg twice daily) for 60 days, regardless of laboratory test results. Nasal swab testing (by culture or PCR) can confirm exposure to anthrax in large groupings, but a negative swab does not exclude exposure in an individual. Persons exposed to penicillinsusceptible strains may receive prophylaxis with high-dose oral penicillin or amoxicillin in limited circumstances, but fluoroquinolones or doxycycline is preferred [20]. 
The anthrax vaccine (AVA-Biothrax, BioPort Corporation, Lansing, Michigan, USA) is the only licensed human anthrax vaccine in the United States and has received licensure in Italy, Germany, the United Kingdom, France, the Netherlands, Poland, and Singapore as of 2018. The vaccine is derived from supernatant material from cultures of a toxigenic, nonencapsulated strain of B. anthracis. Approximately 95\% of individuals seroconvert after the third dose of vaccine; the US military currently uses a six-dose series. Headache and other systemic symptoms have been reported in $1 \%(101 / 10,722)$ of US military recipients, with injection site reactions in $3.6 \%$ [24].

\section{Plague (Yersinia pestis)}

Plague is caused by Yersinia pestis, a gram-negative bacillus and a relative of common pathogens including Escherichia coli and Klebsiella. Y. pestis is most often transmitted to humans from a rodent or rabbit reservoir via flea vectors, principally the species Xenopsylla cheopis worldwide [33] and Oropsylla montana in North America [34]. Other potential routes of transmission include direct contact with infected body fluids and the inhalation of infected respiratory droplets $[35,36]$. Similar to other gram-negative infections, the lipopolysaccharide (LPS) endotoxin associated with its outer cell membrane is a major drive of virulence, implicated in the systemic inflammatory response, acute respiratory distress syndrome, and multiorgan failure associated with fatal plague [37, 38].

Other than malaria and possibly the modern human immunodeficiency virus (HIV) epidemic, few infections have had as profound effect on human history as plague. The "Justinian Plague" of the sixth century CE took the lives of an estimated 100 million people, including a Roman emperor; the better-known "Black Death" of the fourteenth century CE was responsible for over 40 million deaths, or a third of the population of Europe. In modern times, outbreaks of plague have struck China in the late nineteenth century and Vietnam during the 1960s [39]. Contemporary plague remains endemic in sub-Saharan Africa and Madagascar, where over $90 \%$ of current cases occur. In Madagascar alone, there were over 13,000 suspected cases between 1998 and 2016 [40], with a new outbreak in 2017 leading to 2400 additional cases and over 200 deaths [41].

Like anthrax, the CDC classifies plague as a Category A threat agent and potential bioweapon. An aerosolized release of $50 \mathrm{~kg}$ of Yersinia pestis over a population of five million people is estimated to be capable of causing 150,000 infections and 36,000 deaths [42]. Intentional dispersion of Yersinia pestis as an aerosol will lead to outbreaks of pneumonic plague, while the release of infected fleas will typically result in bubonic or septicemic plague outbreaks [36, 42, 43]. Historically, plague was described as a bioweapon in 1346 when the Tartars besieging the city of Kaffa catapulted the corpses of plague victims in the city. Plague has been used as a bioweapon by the military forces of Russia against Sweden and of Japan against China. 
The biowarfare program of the United States had plague in its arsenal before the destruction of the US biological weapon stockpile in the early 1970s.

The clinical manifestations of plague vary depending on the route of exposure. Similar to anthrax, plague exists in a primarily cutaneous and lymphatic form, bubonic plague, and a respiratory form, pneumonic plague. Both modes of plague can be complicated by a third systemic form, septicemic plague. The incubation period and clinical manifestations vary according to mode of transmission. Eightyfive percent of plague cases diagnosed in the United States are bubonic, 10-12\% are primary septicemic, and roughly $3 \%$ are primary pneumonic plague [43]. Bubonic plague may progress to septicemic or pneumonic plague in $23 \%$ and $9 \%$ of cases, respectively. Data on plague in pregnancy is limited [36, 44-47]. Less common forms of plague, such as pharyngeal plague and plague meningitis, occur less frequently.

Bubonic plague is the most common form of naturally occurring plague. After entering the body through a fleabite, bacteria migrate via cutaneous lymphatics to the regional lymph nodes. After evading host defenses, $Y$. pestis replicates within lymph nodes, with the resulting lymphadenitis producing the signature lesion known as the "bubo." Most buboes develop in the groin, axilla, or neck. These enlarged lymph nodes are necrotic and contain dense concentrations of bacteria [48, 49]. Endotoxin and other virulence factors subsequently contribute to disease progression, bacteremia, sepsis, and often death [35-37, 50-54]. Patients with suspected bubonic plague should be managed with strict contact precautions, including the use of gowns, gloves, and surgical masks by clinical staff (Fig 6.3).

Plague is highly contagious by the airborne route. Inhalation of aerosolized droplets of $Y$. pestis from an infected host, including particles from a draining bubo,

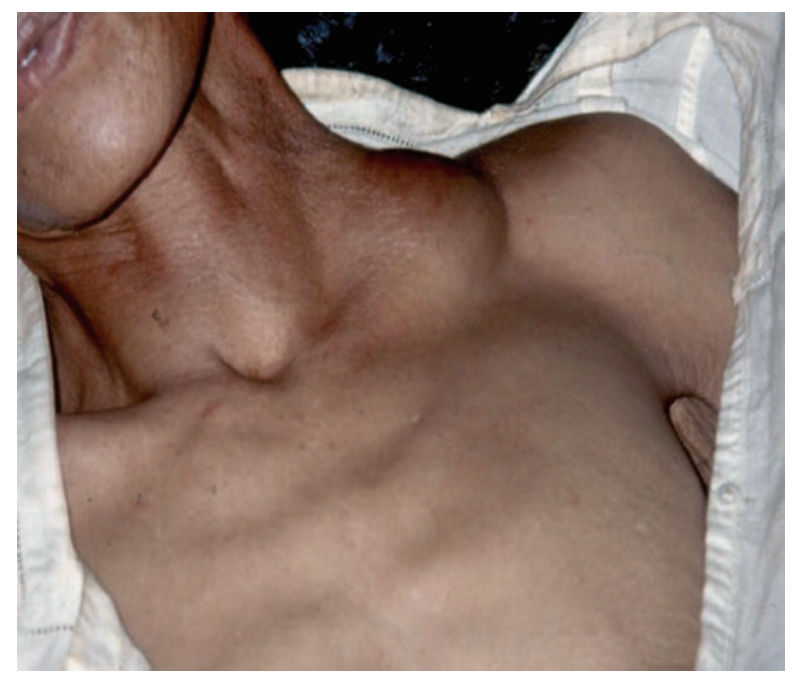

Fig. 6.3 A cervical bubo in a patient in Madagascar with bubonic plague. (Source: Prentice MB, Rahalison L. Lancet 2007; 369:1196-1207) 
results in primary pneumonic plague, a rapidly progressive pneumonia with sepsis that is rapidly fatal without prompt treatment. Secondary pneumonic plague may occur in up to $12 \%$ of individuals with bubonic or primary septicemic plague following the hematogenous spread of $Y$. pestis to the lungs. After 1-6 days of incubation, there is a rapid onset of fever, dyspnea, chest pain, and a productive cough. Acute hypoxemic respiratory failure is common and often requires mechanical ventilation. Bilateral alveolar opacities, pleural effusions, and occasional cavitation are common features on chest radiography. Secondary pneumonic plague may have a nodular, miliary appearance associated with hematogenous spread. Hilar node enlargement is often present [55].

Because of the high risk of transmission, the strict use of droplet precautions by clinical staff is mandatory, in addition to gowns and glove use, until effective antimicrobial therapy has been received by the patient for at least 48 hours. Chemoprophylaxis should be given to potentially exposed personnel. Although N95 respirators are not strictly necessary for protection against plague, other highconsequence pathogens presenting with fulminant respiratory disease do require such protection. Given the rarity of plague in most settings, strong consideration for N95 respirator use should be made in the initial phases of evaluation of suspected plague [56-58]. The untreated mortality rate of primary pneumonic plague is $100 \%$ [59] (Fig. 6.4).

Primary septicemic plague results from the direct inoculation of $Y$. pestis bacilli into the bloodstream, presenting as a febrile sepsis syndrome similar to other gramnegative bacteremias with delirium, hypotension, and nausea. Secondary septicemic plague occurs as a result of progression of either bubonic or pneumonic
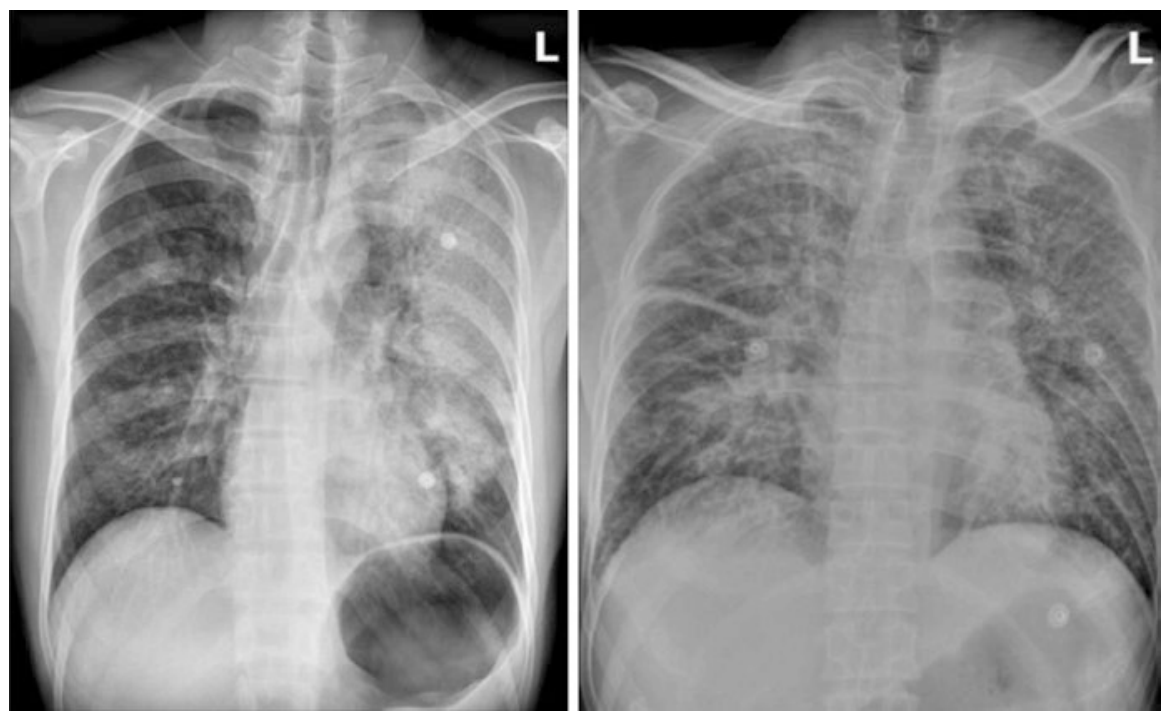

Fig. 6.4 Posteroanterior chest radiographs of patients with pneumonic plague (Source: Lin YF et al., BMC Infect Dis 2016;16:85) 
infections with resulting bacteremia. Meningitis infrequently occurs after hematogenous spread [35, 36]. Abdominal pain, hepatosplenomegaly, disseminated intravascular coagulation, digital gangrene, and purpura fulminans are common features. Similar to pneumonic plague, untreated mortality rate of septicemic plague is $100 \%$, with a high mortality even with rapid critical care intervention [36, 40, 60, 61].

The laboratory diagnosis of plague is based on general hematologic and chemical parameters, culture, serology, and molecular assays. A leukocytosis with neutrophilic predominance and band forms is typical, with coagulopathy, increased levels of liver transaminases, and elevated creatinine occurring in more severe illness. Gram stains of lymph node aspirates, sputum, or blood may demonstrate gram-negative bacilli with bipolar staining, similar to other Enterobacteriaceae. Cultures may be positive for Y. pestis within 24-48 hours. Although some automated bacterial identification systems may misidentify $Y$. pestis, newer mass spectrometry systems based on matrix-assisted laser desorption/ionization time of flight (MALDI-TOF) can identify $Y$. pestis rapidly and reliably following culture growth [62]. Additional tests for detection and confirmation include detection of the $Y$. pestis F1 antigen, IgM immunoassays, PCR, and immunohistochemistry on formalinfixed tissues [63]; these tests are most often available at regional and national reference laboratories, such as the CDC and Laboratory Response Network in the United States or the Emerging and Vector-borne Diseases Programme in the European Union.

Plague should be suspected in persons with fever and lymphadenopathy if they reside in, or have recently traveled to, a plague-endemic area and if bipolar-staining, gram-negative bacilli are seen in affected tissues. The diagnosis of plague should be presumed if immunofluorescence staining of smear or material is positive for the presence of $Y$. pestis F1 antigen or if a single serum specimen shows levels of antibody to the F1 antigen at a titer of 1:10 or greater. Confirmation of plague may be based on a single anti-F1 antibody titer of more than 1:128 dilution or a fourfold rise in paired anti-F1 antibody titers [64]. Multiple cases of pneumonic plague in a nonendemic area should raise concern for bioterrorism. Treatment of suspected plague should not be delayed while awaiting diagnostic confirmation, although preantibiotic cultures and specimens should be obtained as best possible.

The recommended antimicrobial drugs for the treatment of plague are streptomycin or, more commonly, gentamicin. Current US recommendations are listed on Table 6.2. Doxycycline has shown efficacy comparable to gentamicin in a small randomized trial in patients with principally bubonic plague [65]. Fluoroquinolones and chloramphenicol are alternative agents with acceptable efficacy [66-69]. Methylprednisolone and imipenem have shown evidence of efficacy in murine models of plague but lack supporting human data at this time [70, 71]. Treatment should last for 10-14 days. Oral therapy may be initiated once a patient demonstrates clinical stabilization and improvement.

The intentional release of plague, with exposure of large numbers of patients through a presumably respiratory route, may require alternative approaches to therapy. Symptomatic patients should ideally receive treatment with a parenteral aminoglycoside as described above, but oral ciprofloxacin (taken as $500 \mathrm{mg}$ twice daily) 
and doxycycline (100 mg twice daily) are appropriate options for treatment and for post-exposure prophylaxis, including for persons who come within 2 meters of an infected patient with pneumonic plague [72].

In addition to appropriate post-exposure prophylaxis, the prevention of plague relies on careful infection prevention practices. There is presently no commercially available vaccine against plague. Patients suspected of plague should be placed immediately into droplet precautions, with access to the patient room restricted to essential staff. Gowns, gloves, surgical masks, and eye protection should be worn by all staff. Aerosolizing procedures should be kept to an absolute minimum and avoided if possible. As noted before, negative pressure isolation with N95 masks is not necessary for plague, although infections that may present similarly to pneumonic plague (e.g., severe coronavirus infections such as SARS or MERS) may require negative pressure rooms or PAPRs, thus requiring a higher level of protection while diagnostic testing is underway. Following 48 hours of therapy with appropriate antibiotics and with clear clinical improvement, patients with both nonpneumonic plague and pneumonic plague may be removed from isolation [73] (Table 6.3).

Table 6.3 Antimicrobial therapy guidelines for the treatment of plague

\begin{tabular}{|c|c|c|c|c|}
\hline & Antibiotic & Dose & $\begin{array}{l}\text { Route of } \\
\text { administration }\end{array}$ & Notes \\
\hline \multirow[t]{8}{*}{ Adults } & Streptomycin & $1 \mathrm{~g}$ twice daily & IM & $\begin{array}{l}\text { Not widely available in the } \\
\text { United States }\end{array}$ \\
\hline & Gentamicin & $\begin{array}{l}5 \mathrm{mg} / \mathrm{kg} \text { once } \\
\text { daily, or } 2 \mathrm{mg} / \\
\mathrm{kg} \text { loading dose } \\
\text { followed by } \\
1.7 \mathrm{mg} / \mathrm{kg} \\
\text { every } 8 \text { hours }\end{array}$ & IM or IV & $\begin{array}{l}\text { Not FDA approved but } \\
\text { considered an effective } \\
\text { alternative to streptomycin }{ }^{1} \\
\text { Due to poor abscess } \\
\text { penetration, consider } \\
\text { alternative or dual therapy for } \\
\text { patients with bubonic disease }\end{array}$ \\
\hline & Levofloxacin & $\begin{array}{l}500 \mathrm{mg} \text { once } \\
\text { daily }\end{array}$ & IV or PO & $\begin{array}{l}\text { Bactericidal. FDA approved } \\
\text { based on animal studies but } \\
\text { limited clinical experience } \\
\text { treating human plague. A } \\
\text { higher dose ( } 750 \mathrm{mg} \text { ) may be } \\
\text { used if clinically indicated }\end{array}$ \\
\hline & \multirow[t]{2}{*}{ Ciprofloxacin } & $\begin{array}{l}400 \mathrm{mg} \text { every } \\
8-12 \text { hours }\end{array}$ & IV & \multirow{2}{*}{$\begin{array}{l}\text { Bactericidal. FDA approved } \\
\text { based on animal studies but } \\
\text { limited clinical experience } \\
\text { treating human plague }\end{array}$} \\
\hline & & $\begin{array}{l}500-750 \mathrm{mg} \\
\text { twice daily }\end{array}$ & $\mathrm{PO}$ & \\
\hline & Doxycycline & $\begin{array}{l}100 \mathrm{mg} \text { twice } \\
\text { daily or } 200 \mathrm{mg} \\
\text { once daily }\end{array}$ & IV or PO & $\begin{array}{l}\text { Bacteriostatic but effective in } \\
\text { a randomized trial when } \\
\text { compared to gentamicin }{ }^{2}\end{array}$ \\
\hline & Moxifloxacin & $\begin{array}{l}400 \mathrm{mg} \text { once } \\
\text { daily }\end{array}$ & IV or PO & \\
\hline & Chloramphenicol & $\begin{array}{l}25 \mathrm{mg} / \mathrm{kg} \text { every } \\
6 \text { hours }\end{array}$ & IV & $\begin{array}{l}\text { Not widely available in the } \\
\text { United States }\end{array}$ \\
\hline
\end{tabular}


Table 6.3 (continued)

\begin{tabular}{|c|c|c|c|c|}
\hline & Antibiotic & Dose & $\begin{array}{l}\text { Route of } \\
\text { administration }\end{array}$ & Notes \\
\hline \multirow[t]{7}{*}{ Children $^{3}$} & Streptomycin & $\begin{array}{l}15 \mathrm{mg} / \mathrm{kg} \text { twice } \\
\text { daily } \\
\text { (maximum } 2 \mathrm{~g} / \\
\text { day) }\end{array}$ & $\mathrm{IM}$ & $\begin{array}{l}\text { Not widely available in the } \\
\text { United States }\end{array}$ \\
\hline & Gentamicin & $\begin{array}{l}2.5 \mathrm{mg} / \mathrm{kg} / \mathrm{dose} \\
\text { every } 8 \text { hours }\end{array}$ & IM or IV & $\begin{array}{l}\text { Not FDA approved but } \\
\text { considered an effective } \\
\text { alternative to streptomycin. }{ }^{1} \\
\text { Due to poor abscess } \\
\text { penetration, consider } \\
\text { alternative or dual therapy } \\
\text { for patients with bubonic } \\
\text { disease }\end{array}$ \\
\hline & Levofloxacin & $\begin{array}{l}10 \mathrm{mg} / \mathrm{kg} / \mathrm{dose} \\
(\mathrm{maximum} \\
500 \mathrm{mg} / \mathrm{dose})\end{array}$ & IV or PO & $\begin{array}{l}\text { Bactericidal. FDA } \\
\text { approved based on animal } \\
\text { studies but limited clinical } \\
\text { experience treating human } \\
\text { plague }\end{array}$ \\
\hline & >Ciprofloxacin & $\begin{array}{l}15 \mathrm{mg} / \mathrm{kg} / \mathrm{dose} \\
\text { every } 12 \text { hours } \\
\text { (maximum } \\
400 \mathrm{mg} / \text { dose) }\end{array}$ & IV & $\begin{array}{l}\text { Bactericidal. FDA approved } \\
\text { based on animal studies but } \\
\text { limited clinical experience } \\
\text { treating human plague }\end{array}$ \\
\hline & & $\begin{array}{l}20 \mathrm{mg} / \mathrm{kg} / \mathrm{dose} \\
\text { every } 12 \text { hours } \\
\text { (maximum } \\
500 \mathrm{mg} / \mathrm{dose} \text { ) }\end{array}$ & $\mathrm{PO}$ & \\
\hline & Doxycycline & $\begin{array}{l}\text { Weight }<45 \mathrm{~kg} \text { : } \\
2.2 \mathrm{mg} / \mathrm{kg} \text { twice } \\
\text { daily } \\
\text { (maximum } \\
100 \mathrm{mg} / \mathrm{dose} \text { ) } \\
\text { Weight } \geq 45 \mathrm{~kg} \text { : } \\
\text { same as adult } \\
\text { dose }\end{array}$ & IV or PO & $\begin{array}{l}\text { Bacteriostatic, but FDA } \\
\text { approved and effective in a } \\
\text { randomized trial when } \\
\text { compared to gentamicin. }{ }^{2} \text { No } \\
\text { tooth staining after multiple } \\
\text { short courses }^{4}\end{array}$ \\
\hline & $\begin{array}{l}\text { Chloramphenicol } \\
\text { (for children }>2 \\
\text { years) }\end{array}$ & $\begin{array}{l}25 \mathrm{mg} / \mathrm{kg} \text { every } \\
6 \mathrm{~h}(\text { maximum } \\
\text { daily dose, } 4 \mathrm{~g})\end{array}$ & IV & $\begin{array}{l}\text { Not widely available in the } \\
\text { United States }\end{array}$ \\
\hline \multirow[t]{3}{*}{$\begin{array}{l}\text { Pregnant } \\
\text { women }^{3}\end{array}$} & Gentamicin & $\begin{array}{l}\text { Same as adult } \\
\text { dose }\end{array}$ & IM or IV & See notes above \\
\hline & Doxycycline & $\begin{array}{l}\text { Same as adult } \\
\text { dose }\end{array}$ & IV & See notes above \\
\hline & Ciprofloxacin & $\begin{array}{l}\text { Same as adult } \\
\text { dose }\end{array}$ & IV & See notes above \\
\hline
\end{tabular}

$I V$ intravenous; $I M$ intramuscular; $P O$ by mouth

${ }^{1}$ Boulanger et al. [88]

${ }^{2}$ Mwengee et al. [65]

${ }^{3}$ All recommended antibiotics for plague have relative contraindications for use in children and pregnant women; however, use is justified in life-threatening situations

${ }^{4}$ Todd et al. [87]

Source: Centers for Disease Control and Prevention. Accessed online on 11 March 2019 at https:// www.cdc.gov/plague/healthcare/clinicians.html 


\section{Tularemia (Francisella tularensis)}

Tularemia is caused by Francisella tularensis, an intracellular, aerobic gramnegative coccobacillus. Similar to plague, it has a natural small-mammal reservoir of rabbits and rodents. Also similar to plague and anthrax, tularemia occurs in a primarily respiratory form (pneumonic tularemia) and in a primarily cutaneous and lymphatic form (ulceroglandular tularemia). The United States and the former Soviet Union developed biological weapons that could disperse $F$. tularensis in the mid-twentieth century [42], and there remains a concern that F. tularensis could be used as an agent of bioterrorism.

F. tularensis can survive in soil, water, and animal carcasses for many weeks. Chlorination of water prevents its spread through water contamination. As few as ten organisms may be sufficient to cause human disease [74]. Human transmission most often results from tick and flea bites, animal handling, ingestion of contaminated food and water, and inhalation of aerosols. Unlike plague, there is no direct human-to-human transmission. Deliberate aerosolized dispersion of F. tularensis is hypothesized to cause large-scale outbreaks of severe respiratory disease $[9,75]$.

Tularemia is endemic throughout the northern hemisphere. Approximately 80-150 cases per year occur in the United States, with the highest incidence in south-central and western states. The predominant mode of transmission to humans in the United States is by tick bites, most often in spring and summer, with hunting and similar outdoor activities associated with an increased risk of exposure [76]. In Europe, the incidence of tularemia is considerably higher, with over 1000 cases per year in Hungary and the Czech Republic and over 4000 cases per year in Sweden and Finland. Mosquito-borne transmission or consumption of contaminated water predominates as a mode of exposure in parts of Europe, although these vary by country [77].

F. tularensis infected humans via the conjunctiva, respiratory tract, gut, or breaks in the skin. Organisms are taken up by and replicate within macrophages, leading to apoptosis of the macrophage and release into local lymph nodes as well as bacteremia [74]. This bacteremia leads to secondary seeding of the lungs, pleura, spleen, liver, and kidney. Pathologic examination of infected tissue may show granulomatous inflammation with necrosis. Following inhalational exposure, hemorrhagic airway inflammation may progress to pneumonia, pleuritis, and pleural effusion. Human immunity is principally cell-mediated, with antibody responses playing a role in diagnosis but having an uncertain contribution to host defense.

The clinical manifestations of tularemia depend on the site of entry, exposure dose, and host immune factors. Based on the site of initial infection and presenting syndrome, tularemia may be described as primary pneumonic, typhoidal, ulceroglandular, oculoglandular, oropharyngeal, or septic. Ulceroglandular tularemia is the most common form of the infection, typically following with a week of a vector bite or animal contact. A majority of patients present with fever (85\%), with chills $(52 \%)$, headache $(45 \%)$, cough $(38 \%)$, and myalgias $(31 \%)$ occurring in many. Other nonspecific constitutional symptoms occur with variable frequency, such as 
chest and abdominal pain, nausea, vomiting, and diarrhea. The hallmark lesion is a tender papule at the site of initial inoculation which subsequently ulcerates, with painful enlarged lymphadenopathy proximal to the ulcer. This lesion may clinically resemble a plague bubo, and plague must be considered in the differential diagnosis. A purely "glandular" form, with lymphadenopathy but no visible ulcer, can occur as well. In cases of ingestion of contaminated material, an exudative pharyngitis and tonsillitis may develop, with subsequent pharyngeal ulceration and cervical lymphadenopathy. Inoculation of the eye will lead to oculoglandular tularemia, also with accompanying cervical lymphadenopathy. Cases of systemic tularemia without clinically apparent lymphadenopathy are known as typhoidal tularemia. Fever, diarrhea, shock, and meningeal signs are typical (Figs. 6.5 and 6.6).

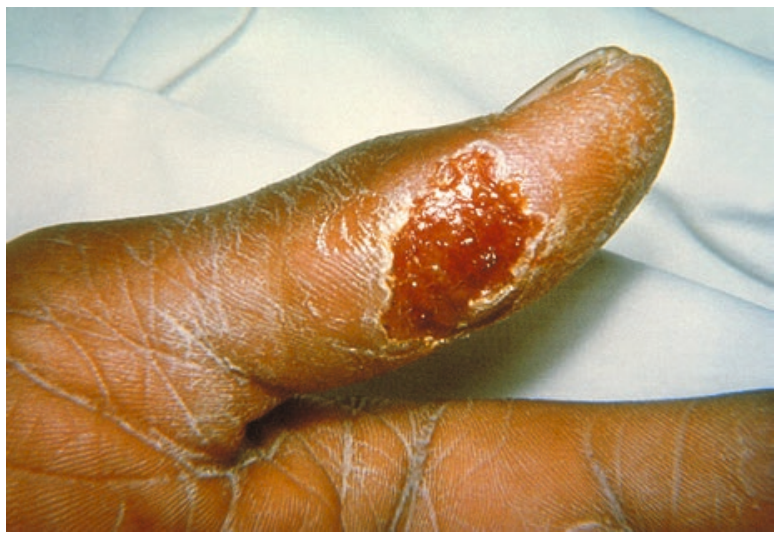

Fig. 6.5 Cutaneous ulcer due to ulceroglandular tularemia. (Source: Public Health Information Library, Centers for Disease Control and Prevention. Accessed online on 11 March 2019 at https:// phil.cdc.gov/Details.aspx?pid=1344)

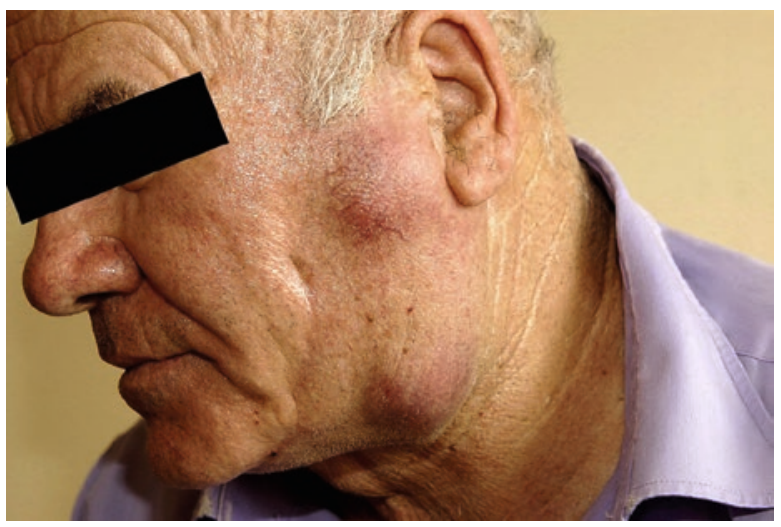

Fig. 6.6 Typical clinical presentation of oculoglandular tularemia with ocular congestion and preauricular and cervical lymphadenitis. (Source: Ulu-Kilic A, Doganay M, Travel Med Infect Dis 2014; 12:609-616) 
Pneumonic tularemia results from the inhalation of aerosolized organisms or from hematogenous spread from other sites of infection. Following the inhalation of the organism, patients may suffer initially from nonspecific fever and chills, followed by a dry or minimally productive cough, pleurisy, dyspnea, and subsequently hemoptysis. Respiratory symptoms were absent in nearly half of patients in a recent series from Finland, however [78]. Pleural effusions are common and may be unilateral or bilateral. Pneumonic tularemia can progress rapidly to acute hypoxemic respiratory failure, disseminated intravascular coagulation, rhabdomyolysis, and eventually multiorgan failure [9, 74]. Virtually any organ may be involved in severe tularemia, including peritonitis, pericarditis, appendicitis, osteomyelitis, and meningitis, although such presentations are less frequent than the more "classic" forms. The mortality rate of untreated pneumonic tularemia is $60 \%$, but rapid institution of antimicrobial therapy reduces the morality rate to $2.5 \%$ or less $[74,79]$.

The diagnosis of tularemia is often delayed due to its nonspecific presenting signs and symptoms, in the case of pneumonic and typhoidal disease, and may be confounded by clinical similarity to plague or anthrax in the case of ulceroglandular disease. Delayed or absent response to routine treatment for skin ulcers or community-acquired pneumonia may serve as diagnostic clues, as may be a history of animal, arthropod, or outdoor freshwater exposure. Routine laboratory tests usually lack distinguishing features and may include a mild lymphocytosis, elevated liver transaminases, and markers of rhabdomyolysis such as elevated serum creatine kinase concentration and urine myoglobin [74, 79].

Chest radiographs most often show unilateral or bilateral airspace opacities, with hilar adenopathy and pleural effusion in approximately $30 \%$ each. Cavitation occurs in approximately $15 \%$ of cases [80]. Chest radiographs may be normal in $7 \%$ of patients, although computed tomography reveals thoracic pathology in the great majority [78].

Although $F$. tularensis may be cultivated from blood, tissue, or sputum in the clinical microbiology laboratory, it requires specialized media (usually cysteineenriched) to grow. Special precautions must be taken for the protection of laboratory staff, similar to plague and anthrax; like the other pathogens of interest, clinicians must notify the microbiology laboratory in the event of a suspected case. Routine microbiology procedures can be performed in Biosafety Level 2 conditions with a biological safety cabinet, but aerosolizing procedures must occur under Biosafety Level 3 conditions [79].

Serologic diagnosis may be utilized given the challenges involved in culturing Francisella. Serum testing by enzyme-linked immunosorbent assay (ELISA) may be negative early in illness but typically produces a fourfold rise in titer over the course of the disease; a single anti-F. tularensis IgG titer of 1:160 is sufficient to support the diagnosis, however [81]. As the ELISA detects antibodies against the bacterial endotoxin, false-positive tests may arise in cases of infections with bacteria that have structurally similar endotoxin, including Brucella, Proteus, and Yersinia species. Confirmatory testing with Western blot, immunofluorescence, or 
microagglutination titer testing will improve the specificity of ELISA testing [8183]. Antigen detection methods, such as direct fluorescent antibodies or immunochemical stains, may be performed on tissue specimens, along with PCR-based testing which may be valuable in outbreak settings $[84,85]$.

The standard treatment for tularemia in adults is streptomycin, $10-15 \mathrm{mg}$ per $\mathrm{kg}$, given intramuscularly (IM) or intravenously (IV) twice daily, but gentamicin, $5 \mathrm{mg}$ per $\mathrm{kg}$, given IM or IV once daily, is equivalent in efficacy and is the standard therapy nowadays. Milder cases of ulceroglandular disease may be treated with doxycycline (IV or oral). Fluoroquinolones or chloramphenicol may be given in selected cases when available; beta-lactams and macrolides are not recommended. Treatment with streptomycin, gentamicin, or ciprofloxacin should be continued for 10 days. Treatment with doxycycline or chloramphenicol should be continued for 14-21 days. Patients beginning treatment with doxycycline, chloramphenicol, or ciprofloxacin can be switched to oral antibiotics when clinically improving and tolerating oral medications. Complete medication recommendations may be seen on Table 6.4.

Chemoprophylactic regimens for the prevention of tularemia are similar to those used for plague. Individuals exposed to $F$. tularensis may be protected against systemic infection if they receive prophylactic antibiotics during the incubation period. For post-exposure prophylaxis, either doxycycline or ciprofloxacin, taken orally twice daily for 14 days, is a recommended regimen. Ciprofloxacin is generally preferred over doxycycline in pregnancy, but either are acceptable given the risk of serious disease and the low risk of skeletal abnormalities in the fetus with such relatively brief tetracycline exposure [79].

A live attenuated vaccine, first developed in Russia, is not generally available but has been given in the United States by the US Army Medical Research Institute of Infectious Diseases (USAMRIID) as an investigational new drug. The vaccine is administered via scarification, similar to smallpox vaccines. Due to dwindling stocks of the original vaccine strain, a newer attenuated strain was tested in a recent phase 2 trial, with the novel vaccine showing high rates of seroconversion among recipients [86].

\section{Disclaimer}

The authors are US military service members. This work was prepared as part of their official duties. Title 17 U.S.C. $\$ 105$ provides that "Copyright protection under this title is not available for any work of the United States Government." Title 17 U.S.C. $\S 101$ defines a US Government work as a work prepared by a military service member or employee of the US Government as part of that person's official duties. The views expressed in this article are those of the authors and do not necessarily reflect the official policy or position of the Department of the Navy, the Department of Defense, nor the US Government. 
Table 6.4 Recommended antimicrobial drugs for the treatment of tularemia

\begin{tabular}{|c|c|c|c|}
\hline & Preferred choices & Alternative choices & $\begin{array}{l}\text { Choices for mass casualty } \\
\text { settings or post-exposure } \\
\text { prophylaxis }\end{array}$ \\
\hline \multirow[t]{2}{*}{ Adults } & $\begin{array}{l}\text { Streptomycin } 1 \mathrm{~g} \mathrm{IM} \\
\text { twice daily } \times 10 \text { days }\end{array}$ & $\begin{array}{l}\text { Doxycycline } 100 \mathrm{mg} \text { IV } \\
\text { twice daily } \times 14-21 \text { days }\end{array}$ & $\begin{array}{l}\text { Doxycycline } 100 \mathrm{mg} \text { orally } \\
\text { twice daily } \times 14 \text { days }\end{array}$ \\
\hline & $\begin{array}{l}\text { Gentamicin } 5 \mathrm{mg} / \mathrm{kg} \\
\mathrm{IM} \text { or IV once } \\
\text { daily } \times 10 \text { days }\end{array}$ & $\begin{array}{l}\text { Chloramphenicol } 15 \mathrm{mg} / \mathrm{kg} \\
\text { IV } 4 \text { times } \\
\text { daily } \times 14-21 \text { days } \\
\text { Ciprofloxacin } 400 \mathrm{mg} \text { IV } \\
\text { twice daily } \times 14-21 \text { days }\end{array}$ & $\begin{array}{l}\text { Ciprofloxacin } 500 \mathrm{mg} \text { orally } \\
\text { twice daily } \times 14 \text { days }\end{array}$ \\
\hline \multirow[t]{2}{*}{ Children } & $\begin{array}{l}\text { Streptomycin } 15 \mathrm{mg} / \\
\mathrm{kg} \mathrm{IM} \text { twice } \\
\text { daily } \times 10 \text { days }\end{array}$ & $\begin{array}{l}\text { Doxycycline } \times 14-21 \text { days: } \\
100 \mathrm{mg} \text { IV twice daily } \\
\text { if }=\text { or }>45 \mathrm{~kg} \\
2.2 \mathrm{mg} / \mathrm{kg} \text { IV twice daily } \\
\text { if }<45 \mathrm{~kg}\end{array}$ & $\begin{array}{l}\text { Doxycycline } \times 14 \text { days } \\
100 \mathrm{mg} \text { orally twice daily } \\
\text { if }=\text { or }>45 \mathrm{~kg} \\
\text { Give } 2.2 \mathrm{mg} / \mathrm{kg} \text { orally } \\
\text { twice daily if }<45 \mathrm{~kg}\end{array}$ \\
\hline & $\begin{array}{l}\text { Gentamicin } 2.5 \mathrm{mg} / \mathrm{kg} \\
\mathrm{IM} \text { or IV three times } \\
\text { daily } \times 10 \text { days }\end{array}$ & $\begin{array}{l}\text { Chloramphenicol } 15 \mathrm{mg} / \mathrm{kg} \\
\text { IV } 4 \text { times } \\
\text { daily } \times 14-21 \text { days } \\
\text { Ciprofloxacin } 15 \mathrm{mg} / \mathrm{kg} \mathrm{mg} \\
\text { IV twice daily } \times 10 \text { days }\end{array}$ & $\begin{array}{l}\text { Ciprofloxacin } 15 \mathrm{mg} / \mathrm{kg} \mathrm{mg} \\
\text { orally twice daily } \times 14 \text { days }\end{array}$ \\
\hline \multirow[t]{2}{*}{$\begin{array}{l}\text { Pregnant } \\
\text { women }\end{array}$} & $\begin{array}{l}\text { Streptomycin } 1 \mathrm{~g} \mathrm{IM} \\
\text { twice daily } \times 10 \text { days }\end{array}$ & $\begin{array}{l}\text { Doxycycline } 100 \mathrm{mg} \text { IV } \\
\text { twice daily } \times 14-21 \text { days }\end{array}$ & $\begin{array}{l}\text { Ciprofloxacin } 500 \mathrm{mg} \text { orally } \\
\text { twice daily } \times 14 \text { days }\end{array}$ \\
\hline & $\begin{array}{l}\text { Gentamicin } 5 \mathrm{mg} / \mathrm{kg} \\
\text { IM or IV once } \\
\text { daily } \times 10 \text { days }\end{array}$ & $\begin{array}{l}\text { Ciprofloxacin } 400 \mathrm{mg} \text { IV } \\
\text { twice daily } \times 10 \text { days }\end{array}$ & $\begin{array}{l}\text { Doxycycline } 100 \mathrm{mg} \text { orally } \\
\text { twice daily } \times 14 \text { days }\end{array}$ \\
\hline
\end{tabular}

Adapted from Dennis et al. [36]

\section{References}

1. Taylor LH, Latham SM, Woolhouse ME. Risk factors for human disease emergence. Philos Trans R Soc Lond Ser B Biol Sci. 2001;356:983-9.

2. Barras V, Greub G. History of biological warfare and bioterrorism. Clin Microbiol Infect. 2014;20:497-502.

3. Meselson M, Guillemin J, Hugh-Jones M, et al. The Sverdlovsk anthrax outbreak of 1979. Science. 1994;266:1202-8.

4. Jaton K, Greub G. Clinical microbiologists facing an anthrax alert. Clin Microbiol Infect. 2014;20:503-6.

5. Vieira AR, Salzer JS, Traxler RM, et al. Enhancing surveillance and diagnostics in anthraxendemic countries. Emerg Infect Dis. 2017;23.

6. Bush LM, Abrams BH, Beall A, Johnson CC. Index case of fatal inhalational anthrax due to bioterrorism in the United States. N Engl J Med. 2001;345:1607-10.

7. Hughes JM, Gerberding JL. Anthrax bioterrorism: lessons learned and future directions. Emerg Infect Dis. 2002;8:1013-4.

8. Friebe S, van der Goot FG, Burgi J. The ins and outs of anthrax toxin. Toxins (Basel). 2016;8.

9. Adalja AA, Toner E, Inglesby TV. Clinical management of potential bioterrorism-related conditions. N Engl J Med. 2015;372:954-62.

10. Shafazand S. When bioterrorism strikes: diagnosis and management of inhalational anthrax. Semin Respir Infect. 2003;18:134-45. 
11. Doganay M, Metan G, Alp E. A review of cutaneous anthrax and its outcome. J Infect Public Health. 2010;3:98-105.

12. Sirisanthana T, Brown AE. Anthrax of the gastrointestinal tract. Emerg Infect Dis. 2002;8:649-51.

13. Purcell B, Worsham P, Friedlander A. Anthrax. In: Dembek ZS, editor. Medical aspects of biological warfare. Falls Church, VA: Borden Institute and US Army Office of the Surgeon General; 2007.

14. Barakat LA, Quentzel HL, Jernigan JA, et al. Fatal inhalational anthrax in a 94-year-old Connecticut woman. JAMA. 2002;287:863-8.

15. Abramova FA, Grinberg LM, Yampolskaya OV, Walker DH. Pathology of inhalational anthrax in 42 cases from the Sverdlovsk outbreak of 1979. Proc Natl Acad Sci U S A. 1993;90:2291-4.

16. Bower WA, Hendricks K, Pillai S, et al. Clinical framework and medical countermeasure use during an anthrax mass-casualty incident. MMWR Recomm Rep. 2015;64:1-22.

17. Mayer TA, Bersoff-Matcha S, Murphy C, et al. Clinical presentation of inhalational anthrax following bioterrorism exposure: report of 2 surviving patients. JAMA. 2001;286:2549-53.

18. Holty JE, Bravata DM, Liu H, Olshen RA, McDonald KM, Owens DK. Systematic review: a century of inhalational anthrax cases from 1900 to 2005. Ann Intern Med. 2006;144:270-80.

19. Holty JE, Kim RY, Bravata DM. Anthrax: a systematic review of atypical presentations. Ann Emerg Med. 2006;48:200-11.

20. Hendricks KA, Wright ME, Shadomy SV, et al. Centers for disease control and prevention expert panel meetings on prevention and treatment of anthrax in adults. Emerg Infect Dis. 2014;20:e130687.

21. Katharios-Lanwermeyer S, Holty JE, Person M, et al. Identifying meningitis during an anthrax mass casualty incident: systematic review of systemic anthrax since 1880. Clinical Infect Dis. 2016;62:1537-45.

22. Meaney-Delman D, Zotti ME, Creanga AA, et al. Special considerations for prophylaxis for and treatment of anthrax in pregnant and postpartum women. Emerg Infect Dis. 2014;20.

23. Bartlett JG, Inglesby TV Jr, Borio L. Management of anthrax. Clin Infect Dis. 2002;35:851-8.

24. Inglesby TV, O'Toole T, Henderson DA, et al. Anthrax as a biological weapon, 2002: updated recommendations for management. JAMA. 2002;287:2236-52.

25. Walsh JJ, Pesik N, Quinn CP, et al. A case of naturally acquired inhalation anthrax: clinical care and analyses of anti-protective antigen immunoglobulin $\mathrm{G}$ and lethal factor. Clin Infect Dis. 2007;44:968-71.

26. Klempner MS, Talbot EA, Lee SI, Zaki S, Ferraro MJ. Case records of the Massachusetts General Hospital. Case 25-2010. A 24-year-old woman with abdominal pain and shock. N Engl J Med. 2010;363:766-77.

27. Webster JI, Moayeri M, Sternberg EM. Novel repression of the glucocorticoid receptor by anthrax lethal toxin. Ann N Y Acad Sci. 2004;1024:9-23.

28. Yamamoto BJ, Shadiack AM, Carpenter S, et al. Efficacy projection of obiltoxaximab for treatment of inhalational anthrax across a range of disease severity. Antimicrob Agents Chemother. 2016;60:5787-95.

29. Yamamoto BJ, Shadiack AM, Carpenter S, et al. Obiltoxaximab prevents disseminated Bacillus anthracis infection and improves survival during pre- and postexposure prophylaxis in animal models of inhalational anthrax. Antimicrob Agents Chemother. 2016;60:5796-805.

30. Migone TS, Bolmer S, Zhong J, et al. Added benefit of raxibacumab to antibiotic treatment of inhalational anthrax. Antimicrob Agents Chemother. 2015;59:1145-51.

31. Kummerfeldt CE. Raxibacumab: potential role in the treatment of inhalational anthrax. Infect Drug Resist. 2014;7:101-9.

32. Kammanadiminti S, Patnaikuni RK, Comer J, Meister G, Sinclair C, Kodihalli S. Combination therapy with antibiotics and anthrax immune globulin intravenous (AIGIV) is potentially more effective than antibiotics alone in rabbit model of inhalational anthrax. PLoS One. 2014;9:e106393. 
33. Andrianaivoarimanana V, Kreppel K, Elissa N, et al. Understanding the persistence of plague foci in Madagascar. PLoS Negl Trop Dis. 2013;7:e2382.

34. Hinnebusch BJ, Bland DM, Bosio CF, Jarrett CO. Comparative ability of Oropsylla montana and Xenopsylla cheopis fleas to transmit Yersinia pestis by two different mechanisms. PLoS Negl Trop Dis. 2017;11:e005276.

35. Smego RA, Frean J, Koornhof HJ. Yersiniosis I: microbiological and clinicoepidemiological aspects of plague and non-plague Yersinia infections. Eur J Clin Microbiol Infect Dis. 1999;18:1-15.

36. Inglesby TV, Dennis DT, Henderson DA, et al. Plague as a biological weapon: medical and public health managemen. Working Group on Civilian Biodefense t. JAMA. 2000;283:2281-90.

37. Atkinson S, Williams P. Yersinia virulence factors - a sophisticated arsenal for combating host defences. F1000Res. 2016;5.

38. Knirel YA, Anisimov AP. Lipopolysaccharide of Yersinia pestis, the cause of plague: structure, genetics, biological properties. Acta Nat. 2012;4:46-58.

39. Khan IA. Plague: the dreadful visitation occupying the human mind for centuries. Trans R Soc Trop Med Hyg. 2004;98:270-7.

40. Andrianaivoarimanana V, Piola P, Wagner DM, et al. Trends of human plague, Madagascar, 1998-2016. Emerg Infect Dis. 2019;25:220-8.

41. Mead PS. Plague in Madagascar - a tragic opportunity for improving public health. N Engl J Med. 2018;378:106-8.

42. Christopher GW, Cieslak TJ, Pavlin JA, Eitzen EM Jr. Biological warfare. A historical perspective. JAMA. 1997;278:412-7.

43. Kwit N, Nelson C, Kugeler K, et al. Human plague - United States, 2015. MMWR Morb Mortal Wkly Rep. 2015;64:918-9.

44. Crook LD, Tempest B. Plague. A clinical review of 27 cases. Arch Intern Med. 1992;152:1253-6.

45. Watson AK, Ellington S, Nelson C, Treadwell T, Jamieson DJ, Meaney-Delman DM. Preparing for biological threats: addressing the needs of pregnant women. Birth Defects Res. 2017;109:391-8.

46. Wong TW. Plague in a pregnant patient. Trop Dr. 1986;16:187-9.

47. Welty TK, Grabman J, Kompare E, et al. Nineteen cases of plague in Arizona. A spectrum including ecthyma gangrenosum due to plague and plague in pregnancy. West $\mathrm{J}$ Med. 1985;142:641-6.

48. Guinet F, Ave P, Filali S, et al. Dissociation of tissue destruction and bacterial expansion during bubonic plague. PLoS Pathog. 2015;11:e1005222.

49. Guinet F, Ave P, Jones L, Huerre M, Carniel E. Defective innate cell response and lymph node infiltration specify Yersinia pestis infection. PLoS One. 2008;3:e1688.

50. Sodeinde OA, Subrahmanyam YV, Stark K, Quan T, Bao Y, Goguen JD. A surface protease and the invasive character of plague. Science. 1992;258:1004-7.

51. Straley SC. The plasmid-encoded outer-membrane proteins of Yersinia pestis. Rev Infect Dis. 1988;10 Suppl 2:S323-6.

52. Straley SC, Skrzypek E, Plano GV, Bliska JB. Yops of Yersinia spp. pathogenic for humans. Infect Immun. 1993;61:3105-10.

53. Lemaitre N, Sebbane F, Long D, Hinnebusch BJ. Yersinia pestis YopJ suppresses tumor necrosis factor alpha induction and contributes to apoptosis of immune cells in the lymph node but is not required for virulence in a rat model of bubonic plague. Infect Immun. 2006;74:5126-31.

54. Zhou D, Han Y, Yang R. Molecular and physiological insights into plague transmission, virulence and etiology. Microbes Infect. 2006;8:273-84.

55. Ketai L, Tchoyoson Lim CC. Radiology of biological weapons--old and the new? Semin Roentgenol. 2007;42:49-59.

56. Siegel JD, Rhinehart E, Jackson M, Chiarello L; the Healthcare Infection Control Practices Advisory Committee. 2007 Guideline for Isolation Precautions: Preventing Transmission of Infectious Agents in Healthcare Settings. Updated September 2018. Accessed online on 11 March 2019 at https://www.cdc.gov/infectioncontrol/guidelines/isolation/index.html. 
57. Pechous RD, Sivaraman V, Stasulli NM, Goldman WE. Pneumonic plague: the darker side of Yersinia pestis. Trends Microbiol. 2016;24:190-7.

58. Silver S. Laboratory-acquired lethal infections by potential bioweapons pathogens including Ebola in 2014. FEMS Microbiol Lett. 2015;362:1-6.

59. Kugeler KJ, Staples JE, Hinckley AF, Gage KL, Mead PS. Epidemiology of human plague in the United States, 1900-2012. Emerg Infect Dis. 2015;21:16-22.

60. Forrester JD, Apangu T, Griffith K, et al. Patterns of human plague in Uganda, 2008-2016. Emerg Infect Dis. 2017;23:1517-21.

61. Hull HF, Montes JM, Mann JM. Septicemic plague in New Mexico. J Infect Dis. 1987;155:113-8.

62. Tourdjman M, Ibraheem M, Brett M, et al. Misidentification of Yersinia pestis by automated systems, resulting in delayed diagnoses of human plague infections--Oregon and New Mexico, 2010-2011. Clin Infect Dis. 2012;55:e58-60.

63. Demeure CE, Dussurget O, Mas Fiol G, Le Guern AS, Savin C, Pizarro-Cerda J. Yersinia pestis and plague: an updated view on evolution, virulence determinants, immune subversion, vaccination, and diagnostics. Genes Immun. 2019;20:357.

64. Koirala J. Plague: disease, management, and recognition of act of terrorism. Infect Dis Clin N Am. 2006;20:273-87, viii.

65. Mwengee W, Butler T, Mgema S, Mhina G, Almasi Y, Bradley C, Formanik JB, Rochester CG. Treatment of plague with gentamicin or doxycycline in a randomized clinical trial in Tanzania. Clin Infect Dis. 2006;42(5):614-21.

66. Russell P, Eley SM, Green M, et al. Efficacy of doxycycline and ciprofloxacin against experimental Yersinia pestis infection. J Antimicrob Chemother. 1998;41:301-5.

67. Steward J, Lever MS, Russell P, et al. Efficacy of the latest fluoroquinolones against experimental Yersinia pestis. Int J Antimicrob Agents. 2004;24:609-12.

68. Heine HS, Hershfield J, Marchand C, et al. In vitro antibiotic susceptibilities of Yersinia pestis determined by broth microdilution following CLSI methods. Antimicrob Agents Chemother. 2015;59:1919-21.

69. Wendte JM, Ponnusamy D, Reiber D, Blair JL, Clinkenbeard KD. In vitro efficacy of antibiotics commonly used to treat human plague against intracellular Yersinia pestis. Antimicrob Agents Chemother. 2011;55:3752-7.

70. Levy Y, Vagima Y, Tidhar A, et al. Adjunctive corticosteroid treatment against Yersinia pestis improves bacterial clearance, immunopathology, and survival in the mouse model of bubonic plague. J Infect Dis. 2016;214:970-7.

71. Heine HS, Louie A, Adamovicz JJ, et al. Evaluation of imipenem for prophylaxis and therapy of Yersinia pestis delivered by aerosol in a mouse model of pneumonic plague. Antimicrob Agents Chemother. 2014;58:3276-84.

72. Inglesby TV, Henderson DA, O'Toole T, Dennis DT. Safety precautions to limit exposure from plague-infected patients. JAMA. 2000;284:1648-9.

73. Siegel JD, Rhinehart E, Jackson M, Chiarello L, the Healthcare infection Control Practices Advisory Committee. 2007 Guideline for isolation precautions: preventing transmission of infectious agents in healthcare settings. Atlanta: Centers for Disease Control and Prevention; 2007.

74. Hepburn MJ, Simpson AJ. Tularemia: current diagnosis and treatment options. Expert Rev Anti-Infect Ther. 2008;6:231-40.

75. Balali-Mood M, Moshiri M, Etemad L. Medical aspects of bio-terrorism. Toxicon. 2013;69:131-42.

76. Centers for Disease C, Prevention. Tularemia - United States, 2001-2010. MMWR Morb Mortal Wkly Rep. 2013;62:963-6.

77. Maurin M, Gyuranecz M. Tularaemia: clinical aspects in Europe. Lancet Infect Dis. 2016; 16:113-24.

78. Vayrynen SA, Saarela E, Henry J, Lahti S, Harju T, Kauma H. Pneumonic tularaemia: experience of 58 cases from 2000 to 2012 in Northern Finland. Infect Dis (Lond). 2017;49:758-64. 
79. Dennis DT, Inglesby TV, Henderson DA, et al. Tularemia as a biological weapon: medical and public health management. JAMA. 2001;285:2763-73.

80. Rubin SA. Radiographic spectrum of pleuropulmonary tularemia. AJR Am J Roentgenol. 1978;131:277-81.

81. Yanes H, Hennebique A, Pelloux I, et al. Evaluation of in-house and commercial serological tests for diagnosis of human tularemia. J Clin Microbiol. 2018;56.

82. Chaignat V, Djordjevic-Spasic M, Ruettger A, et al. Performance of seven serological assays for diagnosing tularemia. BMC Infect Dis. 2014;14:234.

83. Kilic S, Celebi B, Yesilyurt M. Evaluation of a commercial immunochromatographic assay for the serologic diagnosis of tularemia. Diagn Microbiol Infect Dis. 2012;74:1-5.

84. Gunnell MK, Lovelace CD, Satterfield BA, Moore EA, O'Neill KL, Robison RA. A multiplex real-time PCR assay for the detection and differentiation of Francisella tularensis subspecies. J Med Microbiol. 2012;61:1525-31.

85. Yapar D, Erenler AK, Terzi O, Akdogan O, Ece Y, Baykam N. Predicting tularemia with clinical, laboratory and demographical findings in the ED. Am J Emerg Med. 2016;34:218-21.

86. Mulligan MJ, Stapleton JT, Keitel WA, et al. Tularemia vaccine: safety, reactogenicity, "Take" skin reactions, and antibody responses following vaccination with a new lot of the Francisella tularensis live vaccine strain - a phase 2 randomized clinical Trial. Vaccine. 2017;35:4730-7.

87. Todd SR, Dahlgren FS, Traeger MS, Beltrán-Aguilar ED, Marianos DW, Hamilton C, McQuiston JH, Regan JJ. No visible dental staining in children treated with doxycycline for suspected Rocky Mountain spotted fever. J Pediatr. 2015;16e(5):1246-51.

88. Boulanger LL, Ettestad P, Fogarty JD, Dennis DT, Romig D, Mertz G. Gentamicin and tetracyclines for the treatment of human plague: review of 75 cases in New Mexico, 1985-1999. Clin Infect Dis. 2004;38(5):663-9. 